\title{
REVIEW
}

\section{The mutual dependence between bone and gonads}

\author{
Gerard Karsenty \\ Department of Genetics and Development, Columbia University, HHSC 701 West 168th Street, HHSC1602, New York, New York 10032, USA \\ (Correspondence should be addressed to G Karsenty; Email: gk2172@columbia.edu)
}

\begin{abstract}
It has long been known that sex steroid hormones regulate bone mass accrual. This observation raises the testable hypothesis that bone may in turn regulate the synthesis and secretion of sex steroid hormones in one or both genders. This hypothesis is comprised within a more general hypothesis that bone mass, energy metabolism, and reproduction are regulated coordinately. The identification of osteocalcin as an osteoblast-specific
\end{abstract}

secreted molecule allows us to address this question in molecular terms. This review details how the regulation of male fertility by osteocalcin was unraveled, and how osteocalcin signaling in Leydig cells of the testis occurs. It also discusses the implication of this novel mode of regulation of testosterone synthesis observed in males but not in females.

Journal of Endocrinology (2012) 213, 107-114

\section{Introduction}

The principle of mutual dependence between organs as an underlying notion of vertebrate physiology has been verified over and over through mouse genetics. It is clear nowadays that there are interconnections between the different organs in regulation of whole organism physiology. The organs need to communicate with each other to keep our body functional. Based on this view of physiology, it was recently demonstrated that bone is not only a recipient of hormonal inputs but also an endocrine organ of major importance. Multiple studies have shown that bone, via an osteoblast-secreted hormone called osteocalcin, promotes $\beta$-cell proliferation, insulin secretion, and insulin sensitivity in muscle, liver, and white adipose tissue (Lee et al. 2007, Im et al. 2008, Aonuma et al. 2009, Fernandez-Real et al. 2009, Hwang et al. 2009, Kanazawa et al. 2009, Kindblom et al. 2009, Pittas et al. 2009, Ferron et al. 2010, Rached et al. 2010, Winhofer et al. 2010, Yeap et al. 2010, Levinger et al. 2011).

It has long been recognized that bone mass accrual is profoundly regulated by sex steroid hormones, which are necessary for the bone growth and for the maintenance of skeletal integrity (Khosla et al. 2001, Riggs et al. 2002, Nakamura et al. 2007). The biological importance of this regulation is best exemplified by the fact that gonadal failure triggers bone loss in both genders. Estrogen deficiencies at menopause in women and androgen decrease in elderly men are the major pathogenic factors in the development of osteoporosis (Riggs et al. 1998, 2002, Khosla et al. 2001, Vanderschueren et al. 2004, Khosla \& Riggs 2005, Nakamura et al. 2007, Khosla 2010a,b). Considering that endocrine regulation is often subjected to feedback loop mechanisms, the regulation of bone mass accrual by gonads suggests that bone, in its endocrine capacity, may affect the reproductive functions in one or both genders.

This review is a presentation of the unexpected influence the skeletal system exerts on male reproduction.

\section{Sex steroid hormones regulate bone mass accrual}

The sex steroid hormones estrogen and androgen have central roles in the control of sexual maturity and reproduction (Pincus 1962). In addition to their reproductive functions, sex steroid hormones are essential for skeletal development and the maintenance of bone health throughout adult life (Riggs et al. 2002, Vanderschueren et al. 2004, Vandenput \& Ohlsson 2009). Testosterone and estrogen positively influence growth, maturation, and maintenance of the female and male skeleton (Riggs et al. 2002, Vanderschueren et al. 2004, Callewaert et al. 2010a). Their effects are mediated mainly by slow genomic mechanisms through nuclear hormonal receptors, and possibly through fast nongenomic mechanisms by membraneassociated receptors and signaling cascades (Riggs et al. 2002, Vanderschueren et al. 2004, Venken et al. 2008).

\section{Sex steroid hormones regulate bone growth}

Sex steroids play an important role in bone growth and the attainment of peak bone mass. They are, at least in part, 
responsible for the gender differences in bone growth, which emerges during adolescence (Riggs et al. 2002, Vanderschueren et al. 2004, Clarke \& Khosla 2010). Although skeletal size and volume are similar in prepubertal girls and boys (Kelly et al. 1990, Seeman 2001, Vanderschueren et al. 2004, Kirmani et al. 2009, Callewaert et al. 2010a), the sexual dimorphism in bone growth becomes apparent during puberty, at which time men reach higher peak bone mass (Clarke \& Khosla 2010). This skeletal sexual dimorphism is mainly due to a stimulatory androgen action on periosteal bone formation in men, whereas an inhibitory estrogen-related action occurs in women (Bertelloni et al. 1995, Finkelstein et al. 1996, Katznelson et al. 1996, Seeman 2001, Venken et al. 2006, Kirmani et al. 2009). Since an excess of androgen in women is associated with higher bone mineral density, there is evidence that androgens also affect peak bone mass in women (Buchanan et al. 1988, Zborowski et al. 2000, Wei et al. 2010).

In addition to the sex steroid hormones, several studies have shown that other hormones negatively regulated by estrogen, such as growth hormone $(\mathrm{GH})$ and insulin-like growth factor 1 (IGF1), may further contribute to the development of the skeletal sexual dimorphism (Lupu et al. 2001, Venken et al. 2005, Callewaert et al. 2010a,b). IGF1 levels are higher in males vs females during early puberty (Callewaert et al. 2010b,c), and mice lacking GH receptor (GHR), IGF1, or both show a severe bone growth retardation (Lupu et al. 2001). These evidence strongly suggest that skeletal dimorphism in bone growth can not only be attributed to the differences in sex steroid hormone secretion and action in males and females, but also depends on complex gender- and time-specific interactions between several factors (Callewaert et al. 2010a).

\section{Sex steroid hormones maintain skeletal integrity}

Testosterone and estrogens are also crucial for maintaining bone mass accrual during adulthood in the female and male skeleton. The loss of ovarian function underlies the development of osteoporosis (Riggs et al. 2002, Vanderschueren et al. 2004). As a matter of fact, estrogen deficiency is a major pathogenic factor in the bone loss associated with menopause and the development of osteoporosis in postmenopausal women (Riggs et al. 1998, 2002, Khosla et al. 2001, Khosla \& Riggs 2005, Nakamura et al. 2007). After menopause, an imbalance between rates of bone formation and bone resorption, favoring the latter, leads to an accelerated bone loss during the first years after menopause (Garnero et al. 1996, Clarke \& Khosla 2010). This rapid bone loss can be prevented by estrogen administration, and characteristically results in an increase in bone mineral density during the first months of treatment (Lindsay et al. 1976, 1980, Stevenson et al. 1990). Additionally, the loss of testicular function also underlies bone loss in men. Although osteoporosis more commonly affects women, the loss of androgens in males following castration or a decrease in androgen levels related to aging has the same dramatic effect on the skeleton
(Stepan et al. 1989, Riggs et al. 2002, Vanderschueren et al. 2004, Kaufman \& Vermeulen 2005).

The traditional view of the sex steroid hormones presenting androgens and estrogens as a male and female hormones respectively has been reconsidered recently (Callewaert et al. 2010a). A series of evidence shows that estrogens may have a crucial role in the maintenance of bone mass accrual and skeletal homeostasis in elderly men (van den Beld et al. 2000, Bouillon et al. 2004, Mellstrom et al. 2006, Rochira et al. 2007, Araujo et al. 2008). These data suggest that the role of sex steroid hormones in age-related bone loss in women and men is the result of disturbances affecting a complex network regulating bone mass that remains to be further investigated.

\section{Estrogen and androgen mode of action in skeleton}

The sex steroid hormones may influence skeletal physiology, at least in part, by acting directly on bone cells via their classical receptors for estrogens or androgens (Noble et al. 1999, Vidal et al. 1999, Bord et al. 2001). However, mice deficient for $\operatorname{ER} \alpha(\alpha \mathrm{ERKO}), \operatorname{ER} \beta(\beta E R K O)$, double ER (DERKO), and AR (ARKO) did not produce phenotypes similar to those observed in the absence of estrogen or androgen (Couse \& Korach 1999, Couse et al. 1999, Oz et al. 2000, Vidal et al. 2000, Lindberg et al. 2001, Riggs et al. 2002, Vanderschueren et al. 2004, Callewaert et al. 2009). This may be explained by the fact that in these models the levels of sex steroid hormones are abnormally high, and/or that these hormones may also have nongenomic modes of action. Androgen and estrogen can transmit antiapoptotic effects on osteoblasts in vitro with a similar efficiency via either AR or ERs, irrespective of whether the ligand is an androgen or an estrogen (Kousteni et al. 2001, 2002, Manolagas et al. 2002). Hence, at the present time the mechanisms mediating estrogen and androgen function in the bone, via ERs and AR, are not fully elucidated.

Estrogens, mainly $17 \beta$-estradiol, are essential for the maintenance of the balance between bone formation and bone resorption (Riggs et al. 2002, Vanderschueren et al. 2004). At the cellular level, Estrogens affect the generation, lifespan, and functional activity of osteoclasts (Fig. 1). They decrease osteoclast formation and activity, while increasing osteoclast apoptosis (Fig. 1; Hughes et al. 1996, Imai et al. 2009). The role of estrogen regulation of osteoblasts is less clear, and investigations have produced conflicting results and thus will not be presented here. At the molecular level, Estrogens favor osteoclast apoptosis by decreasing the production of cytokines, such as interleukin 1 (IL1), IL6, tumor necrosis factor a (TNF $\alpha)$, and macrophage colonystimulating factor (Hughes et al. 1996, Jimi et al. 1996, Pacifici 1996, Manolagas et al. 2002, Riggs et al. 2002, Xing \& Boyce 2005). In addition, Estrogens suppress bone resorption by inhibiting the osteoclast activity (Fig. 1). Estrogens enhance the expression of transforming growth factor (TGF)- $\beta$ and OPG, inhibitors of osteoclast activity, while decreasing the 


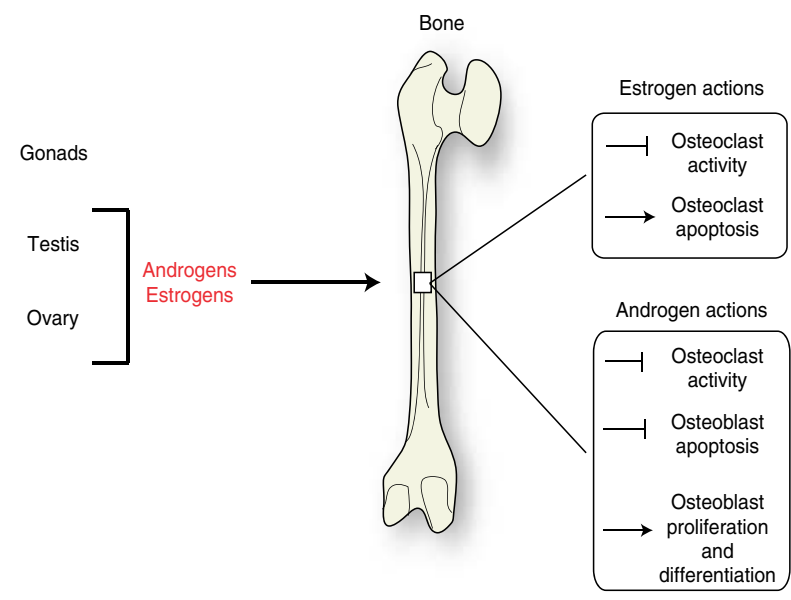

Figure 1 Gonads regulate bone physiology via the sex steroid hormones they produce. Testosterone and estrogen secreted by gonads are essential for the skeletal growth, maturation, and maintenance in both men and women. The sex steroid hormones regulate the apoptosis and/or proliferation of osteoblasts and/or osteoclasts.

expression of RANKL, an activator of osteoclast activity (Bodine et al. 1995, Gill et al. 1998, Tau et al. 1998, Michael et al. 2005). Lastly, Estrogens suppress osteoclast formation by upregulating expression of Fas ligand (Fasl), a gene that belongs to the TNF family (Nakamura et al. 2007, Krum et al. 2008). Therefore, estrogens actions are important physiological regulators of bone remodeling during adulthood.

Androgens favor periostal bone formation in men, and maintain trabecular bone mass and integrity (Fig. 1). At the cellular level, testosterone increases the lifespan of osteoblasts (Fig. 1) by inhibiting IL6 production (Jilka et al. 1992, Manolagas et al. 2002). Furthermore, androgens stimulate the proliferation of osteoblast progenitors and the differentiation of mature osteoblasts (Fig. 1; Kasperk et al. 1989, Kousteni et al. 2001, 2002, Manolagas et al. 2002). At the molecular level, some evidence indicates that androgens favor osteoblast proliferation and differentiation (Fig. 1) by increasing TGF- $\beta$ mRNA, as well as promoting responsiveness to fibroblast growth factor and IGF2 (Bodine et al. 1995, Gill et al. 1998, Riggs et al. 2002). Androgens may also decrease osteoclast formation and bone resorption (Fig. 1) by increasing the production of OPG by osteoblasts (Michael et al. 2005). The net result of these testosterone functions leads to an accrual in bone formation (Fig. 1; Seeman 2001).

\section{The skeleton regulates gonadal functions in males}

The view of bone merely as an assembly of inert calcified tubes characterized only by its scaffolding properties has proven to be wrong. As a matter of fact, the skeleton has emerged in recent years as an endocrine organ of major importance. Multiple studies have shown that osteocalcin, an osteoblast-specific secreted hormone, promotes $\beta$-cell proliferation, insulin secretion, and insulin sensitivity in muscle, liver, and white adipose tissue (Lee et al. 2007, Ferron et al. 2010, Fulzele et al. 2010). Remarkably, it has also been shown that another gene expressed in osteoblasts, Esp (Ptprv), encoding a tyrosine phosphatase called OST-PTP (osteotesticular protein tyrosine phosphatase) exerts metabolic functions opposite to those of osteocalcin (Lee et al. 2007). Genetic and biochemical evidence put OST-PTP as an upstream negative regulator of osteocalcin bioactivity in osteoblasts (Lee et al. 2007, Ferron et al. 2008, 2010, Hinoi et al. 2008, Fulzele et al. 2010). Indeed, Esp ${ }^{-/-}$mice had a metabolic phenotype that is the mirror image of that of Osteocalcin $^{-1-}$ mice (Lee et al. 2007, Ferron et al. 2008).

The hormonal functions of osteocalcin as a bone-derived molecule have raised a number of questions of biological and clinical relevance. The most pressing one was to determine if the skeleton has physiological functions in addition to those exerted on energy metabolism and glucose homeostasis. As mentioned above, that menopause favors bone loss is well established (Riggs et al. 1998, 2002, Khosla et al. 2001, Vanderschueren et al. 2004, Khosla \& Riggs 2005, Nakamura et al. 2007, Khosla 2010a,b). What this medical observation means biologically, as discussed previously, is that gonads regulate bone physiology through the secretion of sex steroid hormones. According to the general principle of feedback control, the regulation of bone mass accrual by gonads implies that bone may affect the reproductive functions in one or both genders. Verifying this hypothesis was of great conceptual importance as it would further enhance the emerging importance of bone as an endocrine organ.

The first evidence supporting this hypothesis came from ex vivo cell assays. Indeed, these studies demonstrated that a factor secreted by osteoblats, but not by other cells of mesodermal origin, could markedly increase testosterone production in testis explants and primary Leydig cells (Oury et al. 2011). The effect of osteoblast supernatants was limited to males; osteoblasts did not stimulate testosterone or estrogens secretion in females. Recently, this novel and important role of osteoblasts has been verified in vivo. Using DTA $_{\text {osb }}$ mice, an osteoblast-less mouse model, ablation of osteoblasts in adult mice profoundly affects circulating testosterone levels (Yoshikawa et al. 2011).

\section{Osteocalcin regulates testosterone biosynthesis}

Since osteocalcin has an important role in the regulation of energy metabolism and glucose homeostasis, it was hypothesized that it may also affect testosterone production. Several experiments have confirmed this hypothesis in vitro and ex vivo. First, using the same co-culture assays described above, the supernatants of wild-type (WT) but not those of Osteocalcin $^{-1-}$ osteoblasts increased testosterone production in testis explants and primary Leydig cells cultures (Oury et al. 2011). Secondly, treating primary Leydig cells with an increasing amount of undercarboxylated osteocalcin, the active form of the hormone, resulted in a dose-dependent increase in 
testosterone secretion (Oury et al. 2011). Thirdly, injection of osteocalcin in WT mice significantly increased circulating levels of testosterone (Oury et al. 2011). Lastly, administration of osteocalcin in mice lacking osteoblasts fully restored testosterone to normal serum levels (Yoshikawa et al. 2011).

A role for osteocalcin in the regulation of testosterone biosynthesis was also demonstrated in vivo (Lee et al. 2007). Osteocalcin $^{-1-}$ mice showed a severe decrease in testis and epidymidal weights, as well as sperm count. These features are associated with the low circulating testosterone levels observed in Osteocalcin ${ }^{-/-}$mice (Oury et al. 2011). Perhaps and more surprisingly, serum luteinizing hormone (LH) levels (the major regulator of testosterone production) were higher in Osteocalcin ${ }^{-/-}$compared to WT male mice. These data suggest a compensatory mechanism is functioning that is insufficient to rescue testosterone production in Osteocalcin $^{-1-}$ mice (Oury et al. 2011). In contrast, analyses of Osteocalcin $^{-/-}$female mice did not show any abnormalities in ovarian, cycling, or in circulating levels of the sex steroid hormones (Oury et al. 2011). These observations suggest that the role of osteocalcin on testosterone production is male specific, and that it acts through a receptor expressed in testis but not in ovaries.
Regulation of sex steroid secretion is subject to feedback inhibition. Indeed, the aromatization of testosterone to estradiol is a large contributing factor to feedback inhibition of testosterone secretion (Schnorr et al. 2001). Accordingly, aromatase inhibition in males results in rather large increases in $\mathrm{LH}$ and follicle-stimulating hormone, causing subsequent elevations in testosterone (Leder et al. 2004, T'Sjoen et al. 2005). Interestingly, Osteocalcindeficient male mice also have significantly increased levels of circulating estradiol leading to a disturbance in testosterone/estradiol ratio (Oury et al. 2011). This observation suggests that osteocalcin may be involved in one of the major mechanisms of feedback inhibition of testosterone secretion. This hypothesis needs to be further investigated.

In summary, these experiments established that osteocalcin is a bone-derived hormone favoring fertility in male mice by promoting testosterone production in Leydig cells (Fig. 2). In other words, it verified that, in at least one gender, there is an endocrine regulation of reproduction by the skeleton (Fig. 2). It also suggests that there may be differences between males and females in the regulation of this function.

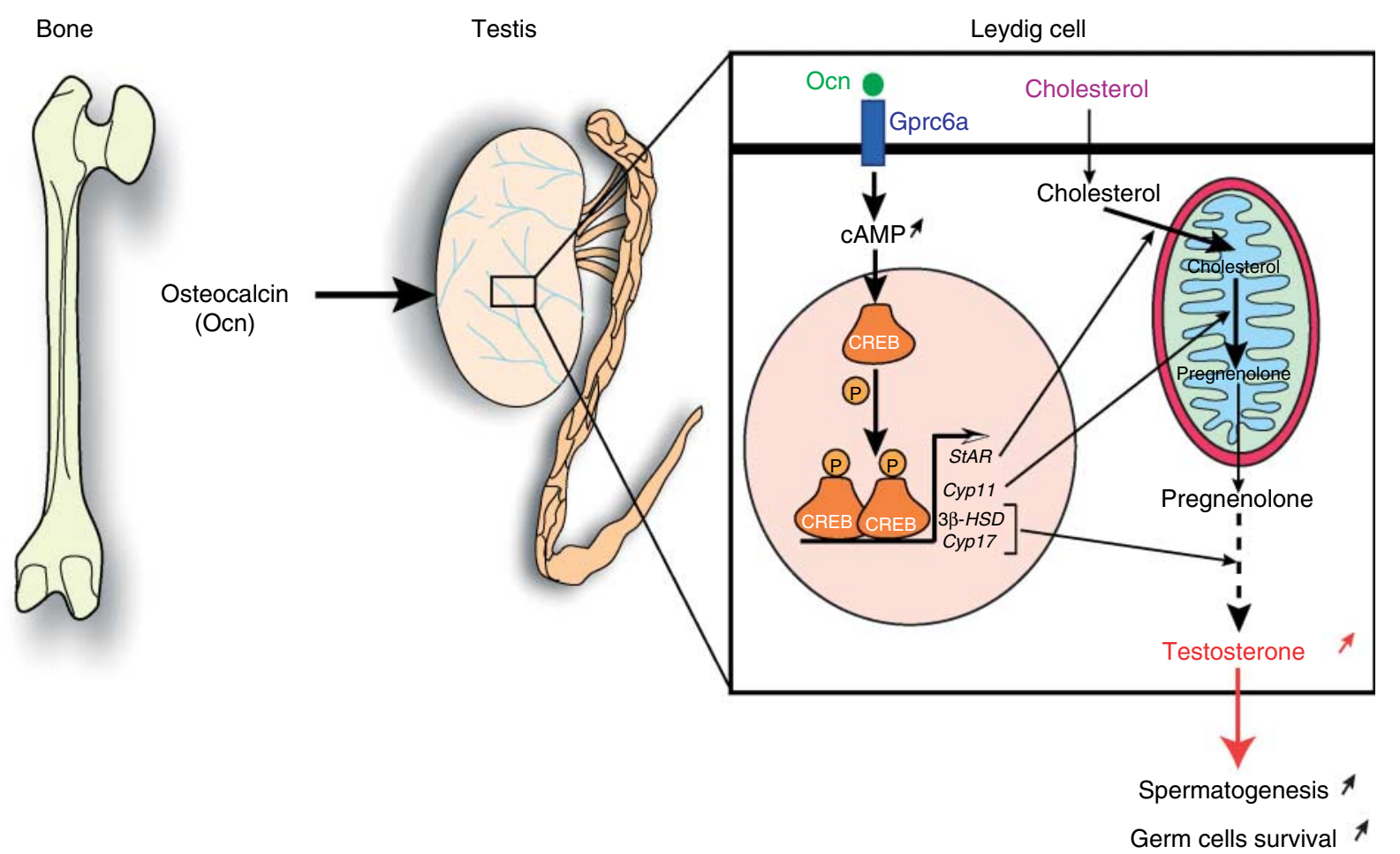

Figure 2 Bone via osteocalcin, an osteoblast-derived hormone, regulates testosterone production in testis. Following its binding to a GPRC6A expressed on Leydig cells of the testes, osteocalcin promotes in a cAMP-response element binding protein (CREB)-dependent manner testosterone production by testis. CREB binds to the promoter regions and activates the expression of several genes encoding for

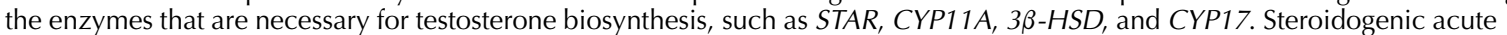
regulatory protein (StAR) is crucial for transport of cholesterol to mitochondria where biosynthesis of steroids is initiated. $C Y P 11 \mathrm{~A}$ encodes the cholesterol side-chain cleavage enzyme (P450scc) that catalyzes the first and rate-limiting step, which converts cholesterol to pregnenolone. $3 \beta-H S D$ and $C Y P 17$ encode two enzymes required during the conversion of pregnenolone to testosterone.

Testosterone is a sex steroid hormone required for many aspects of testicular functions, such as germ cell survival and spermatogenesis. 
Osteocalcin acts on Leydig cells through its receptor GPRC6A

Once the demonstration of the existence of an osteocalcin/testosterone axis was made in vivo, the most important question has been to know its mechanisms of action in testis. In a first attempt to address this question, it was shown that osteocalcin enhances the production cAMP in the $\beta$-cell of the pancreas and in the Leydig cell of the testis. This observation suggested that the, or at least an, osteocalcin receptor would be a $G$ protein-coupled receptor (GPCR) linked to adenylate cyclase. One GPCR, GPRC6A, was a particularly good candidate to be an osteocalcin receptor since Dr Quarles's group has shown that its inactivation in mice results in metabolic and reproduction phenotypes similar to those seen in Osteocalcin ${ }^{-1-}$ mice (Pi et al. 2008). The inactivation of Gprc6a in mice leads to an increase in adiposity, decrease in muscle mass, and low circulating testosterone levels associated with elevated estradiol serum levels in male mice (Pi et al. 2008, Oury et al. 2011). Furthermore, it was proposed that GPRC6A was a calcium-sensing receptor that functioned better in the presence of osteocalcin ( $\mathrm{Pi}$ et al. 2008). In testing this hypothesis in mice, it was first shown that osteocalcin binds to WT but not to Gprc6a-deficient Leydig cells. Secondly, osteocalcin did not stimulate cAMP production in Gprc6a-deficient Leydig cells (Oury et al. 2011). Thirdly, compound heterozygous mice lacking one copy of osteocalcin and one copy of Gprc6a (Osteocalcin $^{+/-} ; \mathrm{Gprc}^{+/-} \mathrm{a}^{+-}$) showed a reproduction phenotype similar, if not identical, in all aspects that observed in osteocalcin $^{-1-}$ or Gprc6a ${ }^{-1-}$ mice (Pi et al. 2008, Oury et al. 2011). Lastly, analyzing the role of osteocalcin in regulation of energy metabolism demonstrated that GPRC6A mediates responses to osteocalcin in $\beta$-cells in vitro, and pancreas in vivo (Pi et al. 2011).

According to the studies of three different groups, Gprc6a is expressed in brain, skeletal muscle, heart, lung, spleen, kidney, liver, fat, and pancreatic $\beta$-cells (Wellendorph \& BraunerOsborne 2004, Kuang et al. 2005, Pi et al. 2005, 2008). It is known that osteocalcin can stimulate insulin secretion in $\beta$-cells and promote insulin sensitivity in peripheral tissues including liver, fat, and muscle (Lee et al. 2007, Ferron et al. 2008). Whether osteocalcin acts on the other tissues expressing Gprc6a remains to be determined. Interestingly, GPRC6A is not expressed in ovaries (Oury et al. 2011). This restricted pattern of expression in gonads may explain why osteocalcin can increase testosterone production from testis, but not from ovaries. The investigation of the role of Grrca in regulation of bone mass accrual has generated contradicting findings (Pi et al. 2008, 2010, Wellendorph et al. 2009), and thus this aspect of Gprc6a function will not be developed further in this review.

Investigating the downstream cascade mediated by GPRC6 $\mathrm{A}$ as an osteocalcin receptor led to the identification of cAMP response element binding protein (CREB) as a transcriptional effector of osteocalcin regulation of testosterone biosynthesis (Fig. 2; Oury et al. 2011). The activation of CREB by osteocalcin signaling favors the expression of key enzymes of testosterone biosynthetic pathway in Leydig cells, such as STAR, CYP11A (CYP11A1), CYP17 (CYP17A1), and $3 \beta-H S D$ (Fig. 2; Oury et al. 2011). Interestingly, the inactivation of osteocalcin in mice does not affect the expression of the aromatase gene, Cyp19a, responsible for estrogen synthesis (Oury et al. 2011).

\section{Conclusion}

The unraveling of this novel endocrine role of the skeleton indicates that no organ is left out of the integrating processes required to allow vertebrates to fulfil their physiological functions. This is consistent with the idea that organisms are integrated entities fulfilling their specific functions, and not as isolated group of distinct cell types. When this concept was applied to the skeleton it has yielded surprising results. But, are these findings really surprising? As a matter of fact, if one considers the unique features of bone and the energetic cost that the perpetual cycle of destruction/formation that characterizing bone modeling and remodeling entails, one might find them not so surprising. Rather it serves as a reminder that physiology has to be studied in the context of evolution, the original purpose of physiological functions being to allow survival, in that case bone growth and ambulation, in difficult conditions and not under the light of degenerative diseases that did not exist when these functions emerged.

This foray in bone physiology is evidence that asking why a given physiological function was created may lead to further discovery of interorgan connections. This in turn may allow a better understanding of the pathogenesis of degenerative diseases, and possibly the design of adapted therapies for these diseases. This is the ultimate purpose of an integrated approach physiology illustrated in this review.

\section{Declaration of interest}

The author declares that there is no conflict of interest that could be perceived as prejudicing the impartiality of the review.

\section{Funding}

This work was supported by the NIH Grant (grant number: 5 R01 DK058883).

\section{References}

Aonuma H, Miyakoshi N, Hongo M, Kasukawa Y \& Shimada Y 2009 Low serum levels of undercarboxylated osteocalcin in postmenopausal osteoporotic women receiving an inhibitor of bone resorption. Tohoku Journal of Experimental Medicine 218 201-205. (doi:10.1620/tjem.218.201)

Araujo AB, Travison TG, Leder BZ \& McKinlay JB 2008 Correlations between serum testosterone, estradiol, and sex hormone-binding globulin and bone mineral density in a diverse sample of men. Journal of Clinical Endocrinology and Metabolism 93 2135-2141. (doi:10.1210/jc.2007-1469) van den Beld AW, de Jong FH, Grobbee DE, Pols HA \& Lamberts SW 2000 Measures of bioavailable serum testosterone and estradiol and their 
relationships with muscle strength, bone density, and body composition in elderly men. Journal of Clinical Endocrinology and Metabolism 85 3276-3282. (doi:10.1210/jc.85.9.3276)

Bertelloni S, Baroncelli GI, Battini R, Perri G \& Saggese G 1995 Shortterm effect of testosterone treatment on reduced bone density in boys with constitutional delay of puberty. Journal of Bone and Mineral Research 10 1488-1495. (doi:10.1002/jbmr.5650101009)

Bodine PV, Riggs BL \& Spelsberg TC 1995 Regulation of c-fos expression and TGF- $\beta$ production by gonadal and adrenal androgens in normal human osteoblastic cells. Journal of Steroid Biochemistry and Molecular Biology 52 149-158. (doi:10.1016/0960-0760(94)00165-I)

Bord S, Horner A, Beavan S \& Compston J 2001 Estrogen receptors $\alpha$ and $\beta$ are differentially expressed in developing human bone. Journal of Clinical Endocrinology and Metabolism 86 2309-2314. (doi:10.1210/jc.86.5.2309)

Bouillon R, Bex M, Vanderschueren D \& Boonen S 2004 Estrogens are essential for male pubertal periosteal bone expansion. Journal of Clinical Endocrinology and Metabolism 89 6025-6029. (doi:10.1210/jc.2004-0602)

Buchanan JR, Myers C, Lloyd T, Leuenberger P \& Demers LM 1988 Determinants of peak trabecular bone density in women: the role of androgens, estrogen, and exercise. Journal of Bone and Mineral Research 3 673-680. (doi:10.1002/jbmr.5650030613)

Callewaert F, Venken K, Ophoff J, De Gendt K, Torcasio A, van Lenthe GH, Van Oosterwyck H, Boonen S, Bouillon R, Verhoeven G et al. 2009 Differential regulation of bone and body composition in male mice with combined inactivation of androgen and estrogen receptor- $\alpha$. FASEB Journal 23 232-240. (doi:10.1096/fj.08-113456)

Callewaert F, Boonen S \& Vanderschueren D 2010a Sex steroids and the male skeleton: a tale of two hormones. Trends in Endocrinology and Metabolism 21 89-95. (doi:10.1016/j.tem.2009.09.002)

Callewaert F, Sinnesael M, Gielen E, Boonen S \& Vanderschueren D $2010 b$ Skeletal sexual dimorphism: relative contribution of sex steroids, GH-IGF1, and mechanical loading. Journal of Endocrinology 207 127-134. (doi:10.1677/JOE-10-0209)

Callewaert F, Venken K, Kopchick JJ, Torcasio A, van Lenthe GH, Boonen S \& Vanderschueren D 2010c Sexual dimorphism in cortical bone size and strength but not density is determined by independent and time-specific actions of sex steroids and IGF-1: evidence from pubertal mouse models. Journal of Bone and Mineral Research 25 617-626. (doi:10.1359/jbmr.090828)

Clarke BL \& Khosla S 2010 Physiology of bone loss. Radiologic Clinics of North America 48 483-495. (doi:10.1016/j.rcl.2010.02.014)

Couse JF \& Korach KS 1999 Estrogen receptor null mice: what have we learned and where will they lead us? Endocrine Reviews 20 358-417. (doi:10.1210/er.20.3.358)

Couse JF, Hewitt SC, Bunch DO, Sar M, Walker VR, Davis BJ \& Korach KS 1999 Postnatal sex reversal of the ovaries in mice lacking estrogen receptors $\alpha$ and $\beta$. Science 286 2328-2331. (doi:10.1126/ science.286.5448.2328)

Fernandez-Real JM, Izquierdo M, Ortega F, Gorostiaga E, Gomez-Ambrosi J, Moreno-Navarrete JM, Fruhbeck G, Martinez C, Idoate F, Salvador J et al. 2009 The relationship of serum osteocalcin concentration to insulin secretion, sensitivity, and disposal with hypocaloric diet and resistance training. Journal of Clinical Endocrinology and Metabolism 94 237-245. (doi:10.1210/jc.2008-0270)

Ferron M, Hinoi E, Karsenty G \& Ducy P 2008 Osteocalcin differentially regulates $\beta$ cell and adipocyte gene expression and affects the development of metabolic diseases in wild-type mice. PNAS 105 5266-5270. (doi:10.1073/pnas.0711119105)

Ferron M, Wei J, Yoshizawa T, Del Fattore A, DePinho RA, Teti A, Ducy P \& Karsenty G 2010 Insulin signaling in osteoblasts integrates bone remodeling and energy metabolism. Cell 142 296-308. (doi:10.1016/j.cell.2010.06.003)

Finkelstein JS, Klibanski A \& Neer RM 1996 A longitudinal evaluation of bone mineral density in adult men with histories of delayed puberty. Journal of Clinical Endocrinology and Metabolism 81 1152-1155. (doi:10.1210/ jc.81.3.1152)

Fulzele K, Riddle RC, DiGirolamo DJ, Cao X, Wan C, Chen D, Faugere MC, Aja S, Hussain MA, Bruning JC et al. 2010 Insulin receptor signaling in osteoblasts regulates postnatal bone acquisition and body composition. Cell 142 309-319. (doi:10.1016/j.cell.2010.06.002)
Garnero P, Sornay-Rendu E, Chapuy MC \& Delmas PD 1996 Increased bone turnover in late postmenopausal women is a major determinant of osteoporosis. Journal of Bone and Mineral Research 11 337-349. (doi:10.1002/ jbmr.5650110307)

Gill RK, Turner RT, Wronski TJ \& Bell NH 1998 Orchiectomy markedly reduces the concentration of the three isoforms of transforming growth factor $\beta$ in rat bone, and reduction is prevented by testosterone. Endocrinology 139 546-550. (doi:10.1210/en.139.2.546)

Hinoi E, Gao N, Jung DY, Yadav V, Yoshizawa T, Myers MG Jr, Chua SC Jr, Kim JK, Kaestner KH \& Karsenty G 2008 The sympathetic tone mediates leptin's inhibition of insulin secretion by modulating osteocalcin bioactivity. Journal of Cell Biology 183 1235-1242. (doi:10.1083/jcb.200809113)

Hughes DE, Dai A, Tiffee JC, Li HH, Mundy GR \& Boyce BF 1996 Estrogen promotes apoptosis of murine osteoclasts mediated by TGF- $\beta$. Nature Medicine 2 1132-1136. (doi:10.1038/nm1096-1132)

Hwang YC, Jeong IK, Ahn KJ \& Chung HY 2009 The uncarboxylated form of osteocalcin is associated with improved glucose tolerance and enhanced $\beta$-cell function in middle-aged male subjects. Diabetes/Metabolism Research and Reviews 25 768-772. (doi:10.1002/dmrr.1045)

Im JA, Yu BP, Jeon JY \& Kim SH 2008 Relationship between osteocalcin and glucose metabolism in postmenopausal women. Clinica Chimica Acta 396 66-69. (doi:10.1016/j.cca.2008.07.001)

Imai Y, Youn MY, Kondoh S, Nakamura T, Kouzmenko A, Matsumoto T, Takada I, Takaoka K \& Kato S 2009 Estrogens maintain bone mass by regulating expression of genes controlling function and life span in mature osteoclasts. Annals of the New York Academy of Sciences 1173 (Suppl 1) E31-E39. (doi:10.1111/j.1749-6632.2009.04954.x)

Jilka RL, Hangoc G, Girasole G, Passeri G, Williams DC, Abrams JS, Boyce B, Broxmeyer H \& Manolagas SC 1992 Increased osteoclast development after estrogen loss: mediation by interleukin-6. Science 257 88-91. (doi:10.1126/ science.1621100)

Jimi E, Ikebe T, Takahashi N, Hirata M, Suda T \& Koga T 1996 Interleukin$1 \alpha$ activates an NF-kappaB-like factor in osteoclast-like cells. Journal of Biological Chemistry 271 4605-4608. (doi:10.1074/jbc.271.9.4605)

Kanazawa I, Yamaguchi T, Yamamoto M, Yamauchi M, Kurioka S, Yano S \& Sugimoto T 2009 Serum osteocalcin level is associated with glucose metabolism and atherosclerosis parameters in type 2 diabetes mellitus. Journal of Clinical Endocrinology and Metabolism 94 45-49. (doi:10.1210/jc. 2008-1455)

Kasperk CH, Wergedal JE, Farley JR, Linkhart TA, Turner RT \& Baylink DJ 1989 Androgens directly stimulate proliferation of bone cells in vitro. Endocrinology 124 1576-1578. (doi:10.1210/endo-124-3-1576)

Katznelson L, Finkelstein JS, Schoenfeld DA, Rosenthal DI, Anderson EJ \& Klibanski A 1996 Increase in bone density and lean body mass during testosterone administration in men with acquired hypogonadism. Journal of Clinical Endocrinology and Metabolism 81 4358-4365. (doi:10.1210/jc.81. 12.4358)

Kaufman JM \& Vermeulen A 2005 The decline of androgen levels in elderly men and its clinical and therapeutic implications. Endocrine Reviews 26 833-876. (doi:10.1210/er.2004-0013)

Kelly PJ, Twomey L, Sambrook PN \& Eisman JA 1990 Sex differences in peak adult bone mineral density. Journal of Bone and Mineral Research 5 1169-1175. (doi:10.1002/jbmr.5650051112)

Khosla S 2010a Update in male osteoporosis. Journal of Clinical Endocrinology and Metabolism 95 3-10. (doi:10.1210/jc.2009-1740)

Khosla S $2010 b$ Update on estrogens and the skeleton. Journal of Clinical Endocrinology and Metabolism 95 3569-3577. (doi:10.1210/jc.2010-0856)

Khosla S \& Riggs BL 2005 Pathophysiology of age-related bone loss and osteoporosis. Endocrinology and Metabolism Clinics of North America 34 1015-1030, xi. (doi:10.1016/j.ecl.2005.07.009)

Khosla S, Melton LJ III, Atkinson EJ \& O'Fallon WM 2001 Relationship of serum sex steroid levels to longitudinal changes in bone density in young versus elderly men. Journal of Clinical Endocrinology and Metabolism 86 3555-3561. (doi:10.1210/jc.86.8.3555)

Kindblom JM, Ohlsson C, Ljunggren O, Karlsson MK, Tivesten A, Smith U \& Mellstrom D 2009 Plasma osteocalcin is inversely related to fat mass and plasma glucose in elderly Swedish men. Journal of Bone and Mineral Research 24 785-791. (doi:10.1359/jbmr.081234) 
Kirmani S, Christen D, van Lenthe GH, Fischer PR, Bouxsein ML, McCready LK, Melton LJ III, Riggs BL, Amin S, Muller R et al. 2009 Bone structure at the distal radius during adolescent growth. Journal of Bone and Mineral Research 24 1033-1042. (doi:10.1359/jbmr.081255)

Kousteni S, Bellido T, Plotkin LI, O’Brien CA, Bodenner DL, Han L, Han K, DiGregorio GB, Katzenellenbogen JA, Katzenellenbogen BS et al. 2001 Nongenotropic, sex-nonspecific signaling through the estrogen or androgen receptors: dissociation from transcriptional activity. Cell 104 719-730.

Kousteni S, Chen JR, Bellido T, Han L, Ali AA, O'Brien CA, Plotkin L, Fu Q, Mancino AT, Wen Y et al. 2002 Reversal of bone loss in mice by nongenotropic signaling of sex steroids. Science 298 843-846. (doi:10.1126/ science.1074935)

Krum SA, Miranda-Carboni GA, Hauschka PV, Carroll JS, Lane TF, Freedman LP \& Brown M 2008 Estrogen protects bone by inducing Fas ligand in osteoblasts to regulate osteoclast survival. EMBO Journal 27 535-545. (doi:10.1038/sj.emboj.7601984)

Kuang D, Yao Y, Lam J, Tsushima RG \& Hampson DR 2005 Cloning and characterization of a family C orphan G-protein coupled receptor. Journal of Neurochemistry 93 383-391. (doi:10.1111/j.1471-4159.2005.03025.x)

Leder BZ, Rohrer JL, Rubin SD, Gallo J \& Longcope C 2004 Effects of aromatase inhibition in elderly men with low or borderline-low serum testosterone levels. Journal of Clinical Endocrinology and Metabolism 89 1174-1180. (doi:10.1210/jc.2003-031467)

Lee NK, Sowa H, Hinoi E, Ferron M, Ahn JD, Confavreux C, Dacquin R, Mee PJ, McKee MD, Jung DY et al. 2007 Endocrine regulation of energy metabolism by the skeleton. Cell 130 456-469. (doi:10.1016/j.cell.2007. 05.047)

Levinger I, Zebaze R, Jerums G, Hare DL, Selig S \& Seeman E 2011 The effect of acute exercise on undercarboxylated osteocalcin in obese men. Osteoporosis International 22 1621-1626. (doi:10.1007/s00198-010-1370-7)

Lindberg MK, Alatalo SL, Halleen JM, Mohan S, Gustafsson JA \& Ohlsson C 2001 Estrogen receptor specificity in the regulation of the skeleton in female mice. Journal of Endocrinology 171 229-236. (doi:10.1677/joe.0. 1710229)

Lindsay R, Hart DM, Aitken JM, MacDonald EB, Anderson JB \& Clarke AC 1976 Long-term prevention of postmenopausal osteoporosis by oestrogen. Evidence for an increased bone mass after delayed onset of oestrogen treatment. Lancet 1 1038-1041. (doi:10.1016/S0140-6736(76)92217-0)

Lindsay R, Hart DM, Forrest C \& Baird C 1980 Prevention of spinal osteoporosis in oophorectomised women. Lancet 2 1151-1154. (doi:10.1016/S0140-6736(80)92592-1)

Lupu F, Terwilliger JD, Lee K, Segre GV \& Efstratiadis A 2001 Roles of growth hormone and insulin-like growth factor 1 in mouse postnatal growth. Developmental Biology 229 141-162. (doi:10.1006/dbio.2000.9975)

Manolagas SC, Kousteni S \& Jilka RL 2002 Sex steroids and bone. Recent Progress in Hormone Research 57 385-409. (doi:10.1210/rp.57.1.385)

Mellstrom D, Johnell O, Ljunggren O, Eriksson AL, Lorentzon M, Mallmin H, Holmberg A, Redlund-Johnell I, Orwoll E \& Ohlsson C 2006 Free testosterone is an independent predictor of BMD and prevalent fractures in elderly men: MrOS Sweden. Journal of Bone and Mineral Research 21 529-535. (doi:10.1359/jbmr.060110)

Michael H, Harkonen PL, Vaananen HK \& Hentunen TA 2005 Estrogen and testosterone use different cellular pathways to inhibit osteoclastogenesis and bone resorption. Journal of Bone and Mineral Research 20 2224-2232. (doi:10.1359/JBMR.050803)

Nakamura T, Imai Y, Matsumoto T, Sato S, Takeuchi K, Igarashi K, Harada Y, Azuma Y, Krust A, Yamamoto Y et al. 2007 Estrogen prevents bone loss via estrogen receptor $\alpha$ and induction of Fas ligand in osteoclasts. Cell 130 811-823. (doi:10.1016/j.cell.2007.07.025)

Noble B, Routledge J, Stevens H, Hughes I \& Jacobson W 1999 Androgen receptors in bone-forming tissue. Hormone Research 51 31-36. (doi:10.1159/000023310)

Oury F, Sumara G, Sumara O, Ferron M, Chang H, Smith CE, Hermo L, Suarez S, Roth BL, Ducy P et al. 2011 Endocrine regulation of male fertility by the skeleton. Cell 144 796-809. (doi:10.1016/j.cell.2011.02.004)

Oz OK, Zerwekh JE, Fisher C, Graves K, Nanu L, Millsaps R \& Simpson ER 2000 Bone has a sexually dimorphic response to aromatase deficiency. Journal of Bone and Mineral Research 15 507-514. (doi:10.1359/jbmr.2000.15.3.507)
Pacifici R 1996 Estrogen, cytokines, and pathogenesis of postmenopausal osteoporosis. Journal of Bone and Mineral Research 11 1043-1051. (doi:10.1002/jbmr.5650110802)

Pi M, Faber P, Ekema G, Jackson PD, Ting A, Wang N, Fontilla-Poole M, Mays RW, Brunden KR, Harrington JJ et al. 2005 Identification of a novel extracellular cation-sensing G-protein-coupled receptor. Journal of Biological Chemistry 280 40201-40209.

Pi M, Chen L, Huang MZ, Zhu W, Ringhofer B, Luo J, Christenson L, Li B, Zhang J, Jackson PD et al. 2008 GPRC6A null mice exhibit osteopenia, feminization and metabolic syndrome. PLoS ONE 3 e3858. (doi:10.1371/ journal.pone.0003858)

Pi M, Zhang L, Lei SF, Huang MZ, Zhu W, Zhang J, Shen H, Deng HW \& Quarles LD 2010 Impaired osteoblast function in GPRC6A null mice. Journal of Bone and Mineral Research 25 1092-1102.

Pi M, Wu Y \& Quarles LD 2011 GPRC6A mediates responses to osteocalcin in $\beta$-cells in vitro and pancreas in vivo. Journal of Bone and Mineral Research 26 1680-1683. (doi:10.1002/jbmr.390)

Pincus G 1962 Reproduction. Annual Review of Physiology 24 57-84. (doi:10.1146/annurev.ph.24.030162.000421)

Pittas AG, Harris SS, Eliades M, Stark P \& Dawson-Hughes B 2009 Association between serum osteocalcin and markers of metabolic phenotype. Journal of Clinical Endocrinology and Metabolism 94 827-832. (doi:10.1210/jc.2008-1422)

Rached MT, Kode A, Xu L, Yoshikawa Y, Paik JH, Depinho RA \& Kousteni S 2010 FoxO1 is a positive regulator of bone formation by favoring protein synthesis and resistance to oxidative stress in osteoblasts. Cell Metabolism 11 147-160. (doi:10.1016/j.cmet.2010.01.001)

Riggs BL, O'Fallon WM, Muhs J, O'Connor MK, Kumar R \& Melton LJ III 1998 Long-term effects of calcium supplementation on serum parathyroid hormone level, bone turnover, and bone loss in elderly women. Journal of Bone and Mineral Research 13 168-174. (doi:10.1359/jbmr.1998.13.2.168)

Riggs BL, Khosla S \& Melton LJ III 2002 Sex steroids and the construction and conservation of the adult skeleton. Endocrine Reviews 23 279-302. (doi:10.1210/er.23.3.279)

Rochira V, Zirilli L, Madeo B, Aranda C, Caffagni G, Fabre B, Montangero VE, Roldan EJ, Maffei L \& Carani C 2007 Skeletal effects of long-term estrogen and testosterone replacement treatment in a man with congenital aromatase deficiency: evidences of a priming effect of estrogen for sex steroids action on bone. Bone 40 1662-1668. (doi:10.1016/j.bone.2007.01.022)

Schnorr JA, Bray MJ \& Veldhuis JD 2001 Aromatization mediates testosterone's short-term feedback restraint of 24-hour endogenously driven and acute exogenous gonadotropin-releasing hormone-stimulated luteinizing hormone and follicle-stimulating hormone secretion in young men. Journal of Clinical Endocrinology and Metabolism 86 2600-2606. (doi:10.1210/jc.86.6.2600)

Seeman E 2001 Clinical review 137: sexual dimorphism in skeletal size, density, and strength. Journal of Clinical Endocrinology and Metabolism 86 4576-4584. (doi:10.1210/jc.86.10.4576)

Stepan JJ, Lachman M, Zverina J, Pacovsky V \& Baylink DJ 1989 Castrated men exhibit bone loss: effect of calcitonin treatment on biochemical indices of bone remodeling. Journal of Clinical Endocrinology and Metabolism 69 523-527. (doi:10.1210/jcem-69-3-523)

Stevenson JC, Cust MP, Gangar KF, Hillard TC, Lees B \& Whitehead MI 1990 Effects of transdermal versus oral hormone replacement therapy on bone density in spine and proximal femur in postmenopausal women. Lancet 336 265-269. (doi:10.1016/0140-6736(90)91801-G)

Tau KR, Hefferan TE, Waters KM, Robinson JA, Subramaniam M, Riggs BL \& Spelsberg TC 1998 Estrogen regulation of a transforming growth factor- $\beta$ inducible early gene that inhibits deoxyribonucleic acid synthesis in human osteoblasts. Endocrinology 139 1346-1353. (doi:10.1210/en.139. 3.1346)

T'Sjoen GG, Giagulli VA, Delva H, Crabbe P, De Bacquer D \& Kaufman JM 2005 Comparative assessment in young and elderly men of the gonadotropin response to aromatase inhibition. Journal of Clinical Endocrinology and Metabolism 90 5717-5722. (doi:10.1210/jc.2005-0982)

Vandenput L \& Ohlsson C 2009 Estrogens as regulators of bone health in men. Nature Reviews. Endocrinology 5 437-443. (doi:10.1038/nrendo. 2009.112) 
Vanderschueren D, Vandenput L, Boonen S, Lindberg MK, Bouillon R \& Ohlsson C 2004 Androgens and bone. Endocrine Reviews 25 389-425. (doi:10.1210/er.2003-0003)

Venken K, Schuit F, Van Lommel L, Tsukamoto K, Kopchick JJ, Coschigano K, Ohlsson C, Moverare S, Boonen S, Bouillon R et al. 2005 Growth without growth hormone receptor: estradiol is a major growth hormoneindependent regulator of hepatic IGF-I synthesis. Journal of Bone and Mineral Research 20 2138-2149. (doi:10.1359/JBMR.050811)

Venken K, De Gendt K, Boonen S, Ophoff J, Bouillon R, Swinnen JV, Verhoeven G \& Vanderschueren D 2006 Relative impact of androgen and estrogen receptor activation in the effects of androgens on trabecular and cortical bone in growing male mice: a study in the androgen receptor knockout mouse model. Journal of Bone and Mineral Research 21 576-585. (doi:10.1359/jbmr.060103)

Venken K, Callewaert F, Boonen S \& Vanderschueren D 2008 Sex hormones, their receptors and bone health. Osteoporosis International 19 1517-1525. (doi:10.1007/s00198-008-0609-z)

Vidal O, Kindblom LG \& Ohlsson C 1999 Expression and localization of estrogen receptor- $\beta$ in murine and human bone. Journal of Bone and Mineral Research 14 923-929. (doi:10.1359/jbmr.1999.14.6.923)

Vidal O, Lindberg MK, Hollberg K, Baylink DJ, Andersson G, Lubahn DB, Mohan S, Gustafsson JA \& Ohlsson C 2000 Estrogen receptor specificity in the regulation of skeletal growth and maturation in male mice. PNAS $\mathbf{9 7}$ 5474-5479. (doi:10.1073/pnas.97.10.5474)

Wei S, Jones G, Thomson R, Otahal P, Dwyer T \& Venn A 2010 Menstrual irregularity and bone mass in premenopausal women: cross-sectional associations with testosterone and SHBG. BMC Musculoskeletal Disorders 11 288. (doi:10.1186/1471-2474-11-288)

Wellendorph P \& Brauner-Osborne H 2004 Molecular cloning, expression, and sequence analysis of GPRC6A, a novel family C G-protein-coupled receptor. Gene 335 37-46. (doi:10.1016/j.gene.2004.03.003)

Wellendorph P, Johansen LD, Jensen AA, Casanova E, Gassmann M, Deprez P, Clement-Lacroix P, Bettler B \& Brauner-Osborne H 2009 No evidence for a bone phenotype in GPRC6A knockout mice under normal physiological conditions. Journal of Molecular Endocrinology 42 215-223. (doi:10.1677/ JME-08-0149)

Winhofer Y, Handisurya A, Tura A, Bittighofer C, Klein K, Schneider B, Bieglmayer C, Wagner OF, Pacini G, Luger A et al. 2010 Osteocalcin is related to enhanced insulin secretion in gestational diabetes mellitus. Diabetes Care 33 139-143. (doi:10.2337/dc09-1237)

Xing L \& Boyce BF 2005 Regulation of apoptosis in osteoclasts and osteoblastic cells. Biochemical and Biophysical Research Communications 328 709-720. (doi:10.1016/j.bbrc.2004.11.072)

Yeap BB, Chubb SA, Flicker L, McCaul KA, Ebeling PR, Beilby JP \& Norman PE 2010 Reduced serum total osteocalcin is associated with metabolic syndrome in older men via waist circumference, hyperglycemia, and triglyceride levels. European Journal of Endocrinology 163 265-272. (doi:10.1530/EJE-10-0414)

Yoshikawa Y, Kode A, Xu L, Mosialou I, Silva BC, Ferron M, Clemens TL, Economides AN \& Kousteni S 2011 Genetic evidence points to an osteocalcin-independent influence of osteoblasts on energy metabolism. Journal of Bone and Mineral Research 26 2012-2025. (doi:10.1002/jbmr.417) Zborowski JV, Cauley JA, Talbott EO, Guzick DS \& Winters SJ 2000 Clinical review 116: bone mineral density, androgens, and the polycystic ovary: the complex and controversial issue of androgenic influence in female bone. Journal of Clinical Endocrinology and Metabolism 85 3496-3506. (doi:10.1210/jc.85.10.3496)

Received in final form 1 March 2012

Accepted 9 March 2012

Made available online as an Accepted Preprint 9 March 2012 